\title{
COLLABORATION AND CRISIS IN MEGA PROJECTS: A STUDY IN CROSS CORPORATE CULTURE CONFLICT AND ITS RESOLUTION
}

\author{
Karen Smits \\ FIA Business School, São Paulo, Brazil \\ E-mail: Karen@crossculturework.com \\ Robert A. Brownlow \\ Bakke Graduate University, Dallas, Texas, USA \\ E-mail: rbrow2@aol.com \\ Submission: $20 / 10 / 2016$ \\ Revision: 04/11/2016 \\ Accept: 10/11/2016
}

\section{ABSTRACT}

Projects typically involve multiple partners coming together to form a temporary project organization that manages project execution. Partners begin their relationship with soaring aspirations to collaborate but as they move through the project's various phases and they experience friction, especially those related to cultural clashes, their noble aspirations succumb to creeping, if not full blown, crisis. This, in turn, creates lost relationality and compromised execution. Thus, the question: How can project partners manage the integration of differing corporate cultures and work processes to produce the most effective and efficient outcomes? Using the mega project of the Panama Canal Expansion Program, the authors explore how a multicultural project organization moved from dysfunctional relationality to synergistic, self-reinforcing, collaboration. A "Collabyrinth" (Smits, 2013) model explores how participants learned to collaborate in a holding environment saturated with layers of complex cultural difference. The Collabyrinth is composed of six comingling elements: (1) Conflicting Conditions, (2) Submarining, (3) Seeking Consent, (4) Storytelling, (5) Crafting Reciprocal Relations, and (6) Synergizing. 
INDEPENDENT JOURNAL OF MANAGEMENT \& PRODUCTION (IJM\&P)

http://www.ijmp.jor.br

v. 8, n. 2, April - June 2017

ISSN: 2236-269X

DOI: 10.14807/ijmp.v8i2.556

Certain aspects of crisis management are employed to explain intra-collabyrinth dynamics. Those aspects are: (1) Coming of the Forerunners, (2) Acuteness in the Now, (3) Resolution Seeking, and (4) Constructing Relationality. Specific examples of the collabyrinth journey are provided and recommendations are made to harness the positive power of cross-corporate culture collaboration.

Keywords: cross-cultural collaboration, crisis management, collabyrinth model, conflict resolution, Panama Canal Expansion Program

\section{INTRODUCTION}

\subsection{Theoretical Perspective}

Our philosophical grounding for this study fits within the constructionist ontological and interpretive epistemological traditions. In these traditions, social realities are seen as actively constructed, culturally and historically contingent, and laden with moral, public and personal values (SCHWARTZ-SHEA; YANOW, 2012; YBEMA et al., 2009). The constructionist-interpretive methodology informs the various methods through which data for this study was gathered. Central to this approach is that field researchers are 'up close and personal' to better understand the actors' lived experiences (i.e., phenomenology).

The first author conducted an ethnographic study of the Panama Canal Expansion Program. The second author conducted a phenomenologicalethnographic study of school district disruption resulting from a work stoppage. Ethnographic research shows that complex case studies can generate in-depth knowledge for theory building (WELCH; PIEKKARI; PLAKOYIANNAKI; PAAVILAINEN, 2011).

From July 2009 to July 2010 the first author interviewed and observed the project participants' daily practices and documented their lived experiences. From June 2006 to May 2007, the second author conducted interviews, focus groups, and surveys to research how dysfunctional collaboration and functional difference contributed to crisis and its resolution. The focus here is on collaboration in the Expansion Program supported by the underlying influence of crisis.

\subsection{Context}

The project owner, the Panama Canal Authority (further abbreviated as ACP), 
INDEPENDENT JOURNAL OF MANAGEMENT \& PRODUCTION (IJM\&P)

http://www.ijmp.jor.br

v. 8, n. 2, April - June 2017

ISSN: 2236-269X

DOI: 10.14807/ijmp.v8i2.556

initiated the Expansion Program in 2006 to expand and modernize the Panama Canal with an estimated budget of US $\$ 5.25$ billion. A key component in this mega project was the design and construction of the Atlantic and Pacific locks (known as the Third Set of Locks project).

With this set of wider locks the Panama Canal became accessible to very large container ships. To execute the construction of these locks, ACP contracted the consortium Grupo Unidos por el Canal (abbreviated as GUPC), consisting Spanish constructor Sacyr, Italian Impregilo (one of the world's top-ranking construction groups, family owned Belgium dredging company Jan de Nul and Cusa, Panama's leading construction company.

\subsection{Mega Projects and Collaboration}

Mega projects are complex organizational systems composed of multiple, distinctive corporate cultures. These variables create challenges that are exacerbated by geographical distance and differing execution strategies must be dispersed across a complex a dense network of relationships (SCOTT; LEVITT; ORR, 2011). This often creates a highly unstable, conflicting context in which the project's work must be accomplished.

Heifetz and Linsky (2002) call this condition a "holding environment," meaning that work takes place within an environment that shapes its execution and the relationality of its project partners.

Project work is inherently a network of complex interactions informed by each partners' culture and established work practices (BRESNEN; MARSHALL, 2011; ENGWALL, 2003; GRABHER, 2002; VAN MARREWIJK; CLEGG; PITSIS; VEENSWIJK, 2008). When conflictive, these interactions create tensions that imperil collaboration (JOSSERAND; CLEGG; KORNBERGER; PITSIS, 2004).

Hence, project managers are obliged to emphasize inter-organizational collaboration (DIETRICH; ESKEROD; DARLCHER; SANHAWALIA, 2010; HARTMANN; BRESNEN, 2011; VEENSWIJK; BERENDSE, 2008). Project managers with backgrounds in diverse national and organizational cultures tend to develop and promote collaborative governance practices (CLEGG, et al., 2002).

Those without such backgrounds tend to experience collaboration challenges when integrating work processes extant in different corporate cultures. That is to say 
INDEPENDENT JOURNAL OF MANAGEMENT \& PRODUCTION (IJM\&P)

http://www.ijmp.jor.br

v. 8, n. 2, April - June 2017

ISSN: 2236-269X

DOI: 10.14807/ijmp.v8i2.556

that limited experience with the diversity of thought, problem solving, and working together can inhibit one's insights, flexibility, and option-seeking thus making it difficult to effectively work with others. It is a form of corporate ethnocentrism that inhibits effective collaboration.

Originating from the Latin root words com and laborare, collaboration means 'to work together.' Alan Mulally, former CEO of Ford Motor Company, used the phrase, "Working Together" as a mantra for developing the 767 when serving as CEO of Boeing Commercial Airplanes and used it again for leading Ford's revival (HOFFMAN, 2012).

Dietrich, Eskerod, Durocher and Sandhawalia (2010) define collaboration as "a recursive process where people or organizations work together in an intersection of common goals by sharing knowledge, learning and building consensus" (p. 60).

Himmelman (1996) is more pragmatic, defining collaboration as, "a process in which organizations exchange information, alter activities, share resources and enhance each other's capacity for mutual benefit and a common purpose by sharing risks, responsibilities and rewards" (p. 22). We define collaboration as a journey in which people learn to productively and harmoniously work together to achieve a desired end.

"Cooperation" and "coordination" approximate collaboration but are not its equal. Short-term, informal interactions characterize "cooperation," as when organizations maintain a relationship to share information at low levels of risk. Coordination requires more commitment and formal structures than cooperation.

Gittell $(2005,2016)$ has written extensively on relational coordination, a theory suggesting the relationship between high performance and relationality. Collaboration requires an ongoing, strong relationship between organizations that allows them to trust one another and to share knowledge and resources. Collaboration is the strongest form of working together relationship between organizations (KEAST et al., 2007).

In holding environments filled with ambiguity and conflict participants must navigate through their differing work practices. Sackman and Friesl (2007:145) argue that "when people join a project team, their individual identities are still rooted in their various home organizations, their profession and other groupings that they take part 
INDEPENDENT JOURNAL OF MANAGEMENT \& PRODUCTION (IJM\&P)

http://www.ijmp.jor.br

v. 8, n. 2, April - June 2017

ISSN: 2236-269X

DOI: 10.14807/ijmp.v8i2.556

of in their life." Actors enter an environment wherein they must integrate their differing organizational cultures and work practices and let go of some of their cultural assumptions and methods.

Differences in national and organizational culture challenge collaboration in project organizations because seemingly straightforward practices and assumptions may be executed differently in the various project partner organizations (HUXHAM, 1996) and in national cultures that differ from their own. While the literature recognizes collaboration as a key element in effective project management, it is unclear on the importance of partners contributing their own unique corporate cultural perspectives to the project effort.

Most research on collaboration in project management focuses on elements that enhance collaboration among and between project partners. Pitsis et al. (2004), noted essential elements like trust, leadership, culture, and power for achieving collaboration.

Cicmil and Marshall (2005) studied "two-stage tendering," which aims to improve team integration in the construction sector. They noted that two-stage tendering does not solve problems stemming from contradictions among and between partners' competing cultures and deteriorating collaboration (CICMIL; MARSHALL, 2005).

Dietrich et al. (2010) identified factors influencing the quality of collaboration in multi-partner projects. These factors included trust between partners, commitment to the project, cultural proximity and expectations. Scholars rarely address how project participants manage their efforts to collaborate nor do they reveal how the culture (i.e.. holding environment) of the project organization shapes participants' daily interactions (Jones; Lichtenstein, 2008).

In the context of cross-cultural collaboration, where multiple cultures interact and organizational processes merge, actors draw on their past cultural experiences to develop new understandings and processes that enable them to make sense of and live in a world where change is ongoing (BOYACIGILLER ET AL., 2004; HIBBERT; HUXHAM, 2010).

Sometimes this comes through an epiphany. Sometimes it is forced through the pain of crisis. In either case, it is through repeated interactions that project 
participants develop new common understandings redefining their collaborative relationship (PHILIPS; LAWRENCE; HARDY, 2000). Thus, collaboration in a project organization is not just about discarding old meanings and practices, it is also about negotiating new meanings and then developing new practices that adjust existing work processes (HARTMANN; BRESNEN, 2011) .

Studying how this process works can enhance our knowledge of the complexity underling collaboration and identifying crisis forerunner events that may impede collaboration.

\subsection{Holding Environments and Crisis}

Some holding environments are more vulnerable to crisis than others. Mega projects are a case in point and especially mega projects that are layered with cultural difference (e.g., corporate, national, professional/functional). The evolution of crisis hampers normal operations, potentially harms the reputations of project leaders, and receives negative press and governing agency scrutiny.

Generally, there are six phases to managing crisis (BROWNLOW, 2007; 2011). These phases are comingling, do not necessarily occur as independent or linear events, and are described below. These phases are described below and comingling and do not necessarily occur as independent or linear events.

\subsubsection{Phase l: Coming of the Forerunners}

Forerunners are warnings that precede crisis. Successfully identifying forerunners can be challenging because the non-linear dynamics of co-mingling "unique" and "routine" warnings challenge detection. Crisis symptomology is complex and intermingled with multiple components in the holding environment. This is made more complex by corporate and national diversity factors that frame relationality. Successfully identifying and mitigating forerunners resolves issues before they become crisis (e.g., recognizing relationships are dysfunctional before they implode and bring the project to a halt).

\subsubsection{Phase II: Acuteness in the Now}

"Acuteness in the Now" is the persistent, sometimes volatile expansion of negative events accompanied by concerted pressure for immediate resolution. It includes such unpleasantries as negative press and unwanted help from overseeing 
agencies. Working together relationships are tested and trust becomes a major issue as the holding environment becomes saturated with dissonance, dysfunction and aanxiety.

\subsubsection{Phase III: Technical Resolution}

Technical resolution ends the immediate crisis and prepares for returning to normal operations. In the case of relationship crisis, managing aftermath can become its own creeping crisis because it creates stressor and control issues that require leaders to defend themselves against charges of incompetence and/or insensitivity. This was clearly the case in the Panama Canal Expansion Program. It is also often true in labor disputes.

\subsubsection{Phase IV: Post Mortem}

Post mortem, sometimes called "lessons learned" or "after action review," reveals human or process weaknesses that caused the crisis and assesses how such weakness can be mitigated to prevent a recurrence (e.g., learning about cultural difference before being thrust into a mega project layered with cultural complexity).

Post mortem can reveal information that humbles leaders. Humbling comes from questions about why certain warning signs were missed or why mitigating action was not taken sooner or why it was not more decisive or effective. Lessons Learned commonly morph into lessons recorded and stored on someone's hard drive, never to be seen again.

\subsubsection{Phase V: Relationship Recovery/Reconciliation}

Relationship Recovery/Reconciliation involves five integrated, interdependent, and collaborative actions that re-member a fragmented social and political capital network. Reconciliation begins with some form of heuristic reflective practice wherein there is the recognition that relationships must improve for the project to be completed within its cost and schedule parameters (BROWNLOW, 2011). Phase V crisis management corresponds to seeking consent in the Collabyrinth journey.

\subsubsection{Phase VI: Renewal}

For our purposes, renewal is defined as reconstructing the dysfunctional social and political capital network into a more harmonious, synergistic, collaborative 
INDEPENDENT JOURNAL OF MANAGEMENT \& PRODUCTION (IJM\&P)

http://www.ijmp.jor.br

v. 8, n. 2, April - June 2017

ISSN: 2236-269X

DOI: 10.14807/ijmp.v8i2.556

project organization. More specifically, it is moving away from the disruption of dysfunction and toward the synergy of collaboration. Renewal is the end result of synergy.

As noted above, for the purposes of this study, and working with the Collabyrinth, we have integrated and synthesized these six phases into the following components, Coming of the Forerunners, Acuteness in the Now, Resolution Seeking (reconciliation), and Constructing Relationality.

\subsection{The Expansion Program Collabyrinth}

The project organization of the Panama Canal Expansion Program was a maze of different cultures (e.g., national, corporate, professional). Work practices represented each partner's distinctive interests, perspectives, and management structures (SMITS, VAN MARREWIJK, VEENSWIJK, 2015). This complex holding environment required interactants to combine, and eventually integrate, their culturally preferred processes and to let go of some of their traditional methods.

Each had to negotiate their differences to reach consensus on deployment strategies. Negotiations required project participants to reflect upon and modify their corporate cultural preferences to enhance the effectiveness of the project organization. This reflected a form of group reflective process (BOUD; DOCHERTY, 2006).

In essence, project partners were homogeneous in their project management values and basic work principles. Transparency, efficiency, and accountability were paramount. Unfortunately, applying these overarching values to daily work practices initially failed. When project partners actually began working together (i.e., collaborating), their corporate cultures collided. Their level of authority, position in the hierarchy, identity and ways of operating were challenged when opposing viewpoints generated friction among and between the project participants and actors frantically searched for harmony and stability by seeking consent.

The journey towards collaboration is a collabyrinth (Figure 1). The neology of 'collaboration' and 'labyrinth' reflects the complexity of collaboration. Participants must find their way through a complex holding environment filled with treacherous terrain. 


\section{Collabyrinth}

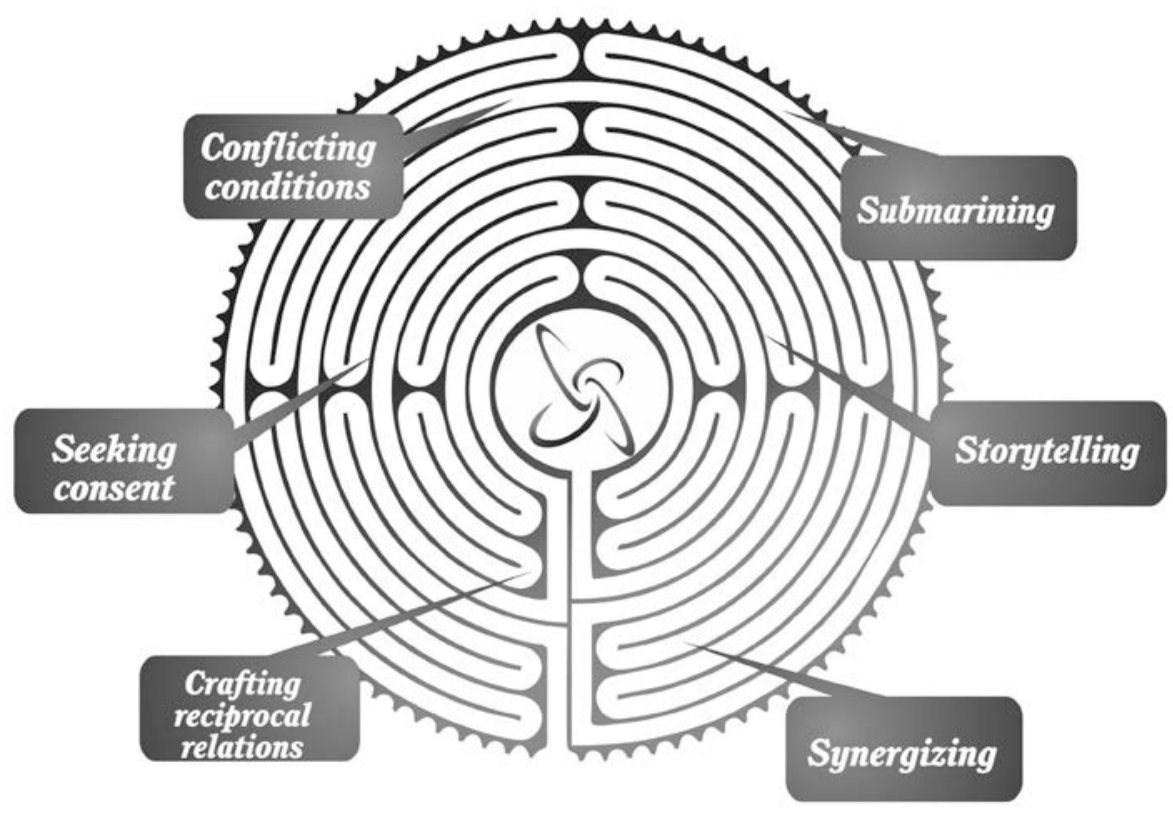

Figure 1: The Collabyrinth

As noted above, the Collabyrinth entails six interconnected practices (not phases) that lead to collaboration: (1) conflicting conditions, (2) seeking consent, (3) crafting reciprocal relations, (4) submarining, (5) storytelling, and (6) synergizing (see Table 1 for detailed explanation).

Like the phases of crisis management, these practices involve interactions that participants employ to make sense of how they can better work together to achieve the project's mission. The six practices manifest how participants manage cultural complexity in the project's holding environment and how their management of that complexity impacts subsequent working together relationships when friction occurs.

These practices are evolutionarily dynamic. That is, as people continuously translate and negotiate these practices they are simultaneously searching for ways through the collabyrinth. Further, like crisis management, the collabyrinth journey is based on transformational learning through reflective practice (MEZIROW, 1991). Put another way, participants reflect on what they are doing and, if needed, modify their behavior to effectively negotiate the power struggles that are inherently part of working together. This can also be seen as a "drilling through the layers of collaboration process," as noted in Figure 2. 


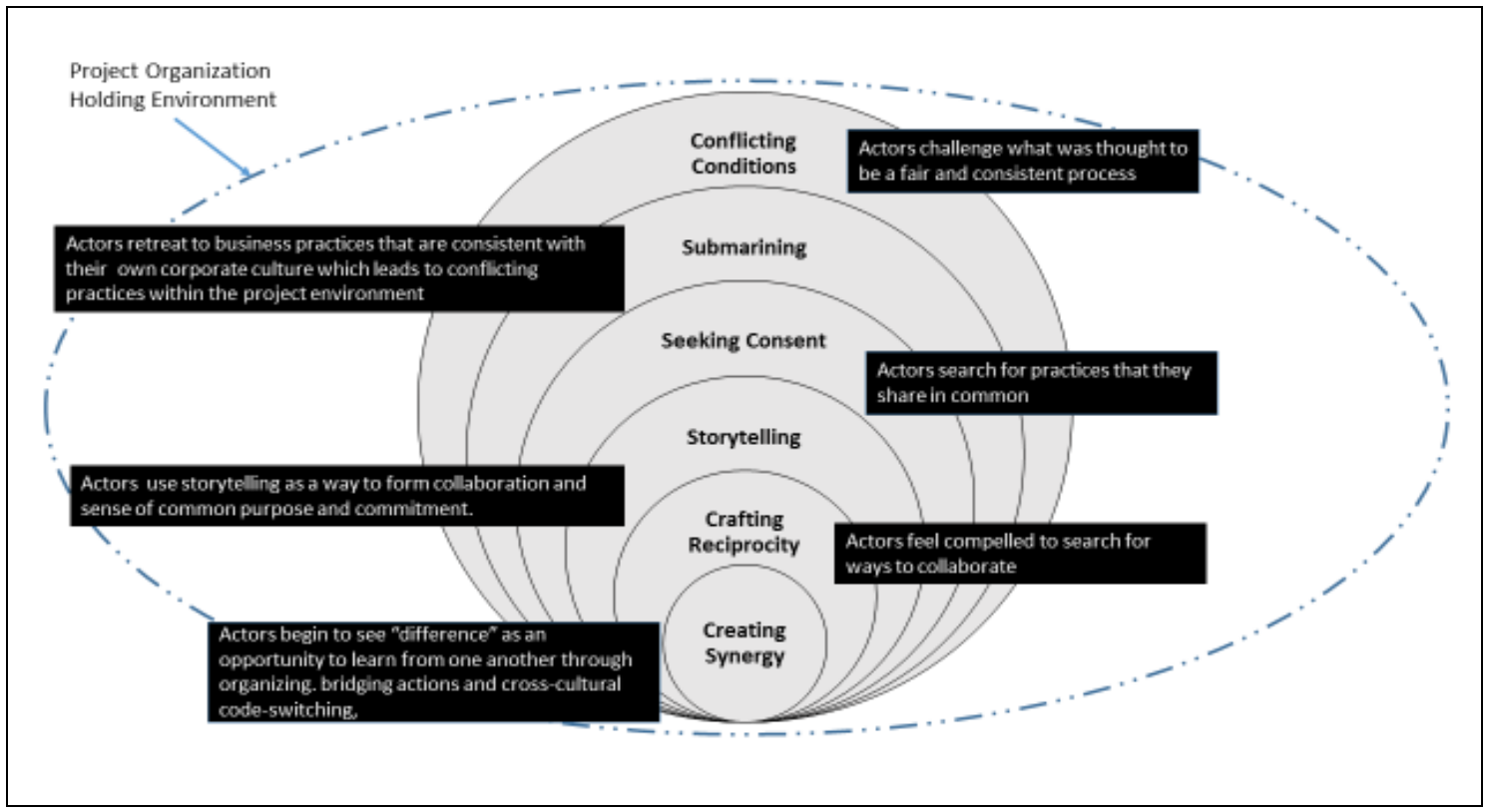

Figure 2: Crisis Management and the Collabyrinth

\section{CRISIS FORERUNNERS HINDERING THE COLLABYRINTH JOURNEY}

Some practices hinder collaboration while others encourage it. Those that hinder can be considered forerunners to crisis. Noted below are the major conflicting conditions that were forerunners to crisis in the Panama Canal Expansion Program.

\section{1. "Suspicious" Tender}

On July 8,2009 , during a public ceremony held in Panama, the consortium Grupo Unidos por el Canal (GUPC) won the tender for the design and construction of locks on the Atlantic and Pacific side of the canal. This was the main component in the Panama Canal Expansion Program. GUPC, a temporary project organization overseeing the construction, was comprised of four companies: Spanish constructor Sacyr, Italian-based engineering company Impregilo, family owned Belgium dredging company Jan de Nul, and Panama's leading construction company CUSA.

GUPC's project bid gained the highest technical score and offered the lowest price (approximately US\$ $3.2 \mathrm{~B}$ ). The proposal attracted immediate concern because it was dramatically lower than the amount the Panama Canal Authority (ACP) had reserved for this aspect of the project. Frequently, proposed prices for construction projects in the infrastructure sector are higher than the budgeted price (FLYVBJERG; HOLM; BUHL, 2002).

It was alleged that GUPC had 'left money on the table' and project partners felt angst over the "suspicious" bid. The consortium was in uproar (FIELDNOTES, 
2009). This forerunner became a creeping crisis exacerbated by the project partners' differing motives for participation. It overshadowed how the expansion project was managed by exerting tremendous cost performance pressure.

\subsection{Culturally Complex Holding Environment}

The work environment was composed of multiple corporate cultures, complete with different work processes, hierarchies, and management styles. This was exacerbated by differing national cultures and related communication styles. An engineer on the Atlantic side of the project, noted:

I have worked in many joint ventures before, but here you can clearly see a difference: the Italians and the Spaniards work a lot different than the Belgians. They are less efficient. Yes, they work more hours a day, but they lose a lot of time chatting with each other. Also, they communicate with drama, it's like a play in a theatre, and they take long breaks. That kind of stuff... (INTERVIEW, May 2010).

In terms of the corporate culture conflict, 'Bart' expresses his opinion about each partner in the project organization:

Sacyr is simply weak and I think they have very little international experience. Okay, they have done some projects in Latin America, but outside of that, nothing I think. Impregilo is a firm with extensive international experience and they are relatively well organized. Of course, they are a bunch of mafiosos... Jan de Nul, well, here you immediately see the difference between 'the northerners' and 'the southerners': we go straight to our goal; we don't walk around the bush (INTERVIEW, June 2010).

"Jerry" underscores the corporate culture differences:

Jan de Nul's people are - they're very different from the Sacyr or Impregilo or the CUSA's people. They're very different in their approach to the work and their demeanor is just much different that of the others (INTERVIEW, June 2010).

Initially, participants disagreed on process issues but quickly realized that regardless of their corporate culture preferences, they needed process consensus to achieve the project's mission. Participants came to understand that layers of cultural complexity were impeding the project's execution strategy. Table 1 describes central components of their collabyrinth journey and its relationship to our synthesized, integrated crisis management process. 
INDEPENDENT JOURNAL OF MANAGEMENT \& PRODUCTION (IJM\&P)

http://www.ijmp.jor.br

v. 8, n. 2, April - June 2017

ISSN: 2236-269X

DOI: 10.14807/ijmp.v8i2.556

Table 1: The Collabyrinth Journey and Crisis Management in the Panama Canal Expansion Program

\begin{tabular}{|c|c|c|}
\hline $\begin{array}{l}\text { Collabyrinth } \\
\text { Components }\end{array}$ & Description & Illustration \\
\hline \multirow{2}{*}{$\begin{array}{l}\text { Conflicting } \\
\text { Conditions }\end{array}$} & $\begin{array}{l}\text { Actors become aware of conflictive } \\
\text { "corporate ethnocentric" practices } \\
\text { that obstruct collaboration. }\end{array}$ & $\begin{array}{l}\text { Discord over bid proposal, cultural } \\
\text { differences, roles and authority } \\
\text { created complexity and friction. }\end{array}$ \\
\hline & $\begin{array}{l}\text { In crisis management: Coming of the } \\
\text { forerunners, early warnings of } \\
\text { impending crisis. }\end{array}$ & $\begin{array}{l}\text { Perceived slights and lost relationality } \\
\text { resulting in poor collaboration and } \\
\text { reduced effectiveness. }\end{array}$ \\
\hline \multirow[t]{2}{*}{ Submarining } & $\begin{array}{l}\text { Participants "clung" to their } \\
\text { preferential way of executing work } \\
\text { processes rather than embrace new } \\
\text { ways and means. }\end{array}$ & $\begin{array}{l}\text { Marking boundaries and defending } \\
\text { them, acting autonomously and "below } \\
\text { the surface". } \\
\text { To cope with sustained conflict, } \\
\text { participants distanced themselves by } \\
\text { focusing on their portion of the contract } \\
\text { and their idiosyncratic knowledge and } \\
\text { skills. } \\
\text { Reliance on their corporately defined } \\
\text { comfort zone prevented process } \\
\text { integration, creating angst between } \\
\text { project partners. }\end{array}$ \\
\hline & $\begin{array}{l}\text { In crisis management: Acuteness in } \\
\text { the now with the accompanying } \\
\text { persistent, sometimes volatile } \\
\text { expansion of negative events } \\
\text { accompanied by extreme pressure } \\
\text { for immediate resolution. }\end{array}$ & $\begin{array}{l}\text { Negative press and intervention from } \\
\text { government agencies and the press } \\
\text { project progress slows. } \\
\text { Stressor and control issues required } \\
\text { leaders to defend themselves against } \\
\text { charges of incompetence and/or } \\
\text { insensitivity. }\end{array}$ \\
\hline \multirow[t]{2}{*}{$\begin{array}{l}\text { Seeking } \\
\text { Consent }\end{array}$} & $\begin{array}{l}\text { Participants begin searching for work } \\
\text { processes and decision criteria that } \\
\text { they can share in common and can } \\
\text { agree to. }\end{array}$ & $\begin{array}{l}\text { Defining cultural differences, and } \\
\text { sharing their passion for their } \\
\text { respective professions. }\end{array}$ \\
\hline & $\begin{array}{l}\text { From Crisis Management: Resolution } \\
\text { Seeking/Reconciliation. }\end{array}$ & $\begin{array}{l}\text { Initiation of reconciliation behaviors to } \\
\text { improve relationality. }\end{array}$ \\
\hline \multirow[t]{2}{*}{ Storytelling } & $\begin{array}{l}\text { Participants use stories to } \\
\text { emphasize the project's importance } \\
\text { and the need for collaboration. }\end{array}$ & $\begin{array}{l}\text { Participants tell stories to share } \\
\text { examples and forge common ground. }\end{array}$ \\
\hline & $\begin{array}{l}\text { From crisis management: Ongoing } \\
\text { resolution seeking. }\end{array}$ & $\begin{array}{l}\text { Forming "Emergent We" emblematic of } \\
\text { high levels of collaboration. }\end{array}$ \\
\hline \multirow{2}{*}{$\begin{array}{l}\text { Crafting } \\
\text { Reciprocal } \\
\text { Relations }\end{array}$} & $\begin{array}{l}\text { Chronic dysfunction creates a strong } \\
\text { desire for collaboration so the project } \\
\text { can be completed. }\end{array}$ & $\begin{array}{l}\text { Organizing activities and boundary } \\
\text { spanning roles are implemented. }\end{array}$ \\
\hline & $\begin{array}{l}\text { From crisis management, } \\
\text { Constructing relationality through } \\
\text { dense social and political capital } \\
\text { networks. }\end{array}$ & $\begin{array}{l}\text { Laying the foundations for synergy, } \\
\text { which creates renewal. }\end{array}$ \\
\hline \multirow[t]{2}{*}{ Synergizing } & $\begin{array}{l}\text { Collaborative learning takes place as } \\
\text { work processes and positive social } \\
\text { and political capital are generated } \\
\text { through integrated work processes. } \\
\text { Cross cultural code switching } \\
\text { becomes a prominent aspect of } \\
\text { working together. }\end{array}$ & $\begin{array}{l}\text { Dysfunction drives actors to adapt best } \\
\text { practices for project completion. } \\
\text { Project achieves high levels of } \\
\text { effectiveness and efficacy through } \\
\text { productive working together } \\
\text { relationships. }\end{array}$ \\
\hline & $\begin{array}{l}\text { From Crisis Management: End } \\
\text { phase of constructing relationality } \\
\text { resulting in high levels of effective }\end{array}$ & Organizational renewal. \\
\hline
\end{tabular}


collaboration.

\section{CRITICAL PRACTICES FOR CONSTRUCTING COLLABORATION}

Once participants realized that working together relationships had to be less contentious they needed to determine how they could construct better relationality. Below we noted practices employed by the project's participants.

\subsection{Seeking Consent}

Seeking consent is the concerted desire, coupled to concerted effort, to improve collaboration. In the Panama Canal Expansion Program seeking consent saw participants reflect on and modify their known and comfortable work practices to forge consensus-driven relationships based on overarching common interest.

This was a negotiated process that included respecting and embracing the cultural complexity in their holding environment and understanding how comingling networks of social capital work in multicultural contexts. Project participants had to continuously reframe their individual corporate work practices and interpersonal interactions to make sense of a fluxing holding environment filled with coalitions. Putnam $(2000,2004)$ refers to such coalitions as dense networks of reciprocal relationships based on shared understandings (which is exactly what participants attempted to do and is also a crucial element in crisis management).

Seeking consent requires shared understandings and recognition of common interests. Dysfunction forced partners to express their feelings about their experiences in a dysfunctional holding environment and to make a complex, conflictive circumstance understandable to them. Seeking consent was a way to end the pain of crisis. Morris (2003) notes that to be in crisis is to be in pain.

In the emotional process of meaning making participants used several communicative practices that included storytelling and dialogue.

\subsection{Storytelling and Dialogue}

As noted in Table 1, stories were introduced into the project's holding environment to promote relationality. Storytelling created new perspectives on work practices by recognizing participants' individual experiences and used that recognition to reshape their collaboration through consensus. Partners told unifying stories about how their roles connected to each. 
INDEPENDENT JOURNAL OF MANAGEMENT \& PRODUCTION (IJM\&P)

http://www.ijmp.jor.br

v. 8, n. 2, April - June 2017

ISSN: 2236-269X

DOI: 10.14807/ijmp.v8i2.556

This led to an "Emergent We" wherein a new, "larger" group arose from interactions among the "smaller" groups that were not cross culturally engaged. Brownlow (2007, 2011) has defined "The Emergent We" as a community transcendent in its commitment to its members and its mission. The Emergent We can be seen as a form of negotiated culture (CLAUSEN, 2007).

Metaphors and dialogue were key to forming an Emergent We. Metaphors were used to safely describe thoughts and feeling about events in the holding environment. Dialogue made storytelling interactive. The meaning-seeking nature of dialogue caused participants to "know," and know that they knew together.

Agreed upon collaboration emerged from "knowing" as people told the truth about their experiences within their part of the relationship network and what those experiences meant for them. Being willing to tell the truth about one's experience carried the responsibility to listen to and accepting the experience of others as being valid.

Story and dialogue revealed that project partners had an event-filled, coherent story that led them to present circumstance (e.g., forerunners, acuteness in the now, seeking consent, constructing relationality, synergy). Those in the story were connected by its drama and had to discern what was essential in themselves and their organization as the worked in a challenging holding environment.

Dialogue crafted reciprocal relations through synergy-seeking which ensured that no partner was marginalized. It became a distinguishing feature of project organization governance. This created faith in a future shaped by collaboration. Wheatley (2003) discusses faith in the future and coming together to build connection, friendship and collaboration.

However, there were still challenges because project partners maintained internal associations of strong friendships (social capital) between persons of similar position and profession within their group but treated other project partners with suspicion. The genuine test of friendliness and collaboration is not in how intra corporate culture members treat each other, but in how they treat others outside their culture who have differing views on important issues (REEVES, 2004).

Participants' motivation to build a productive, working together relationship corresponded to their professional need to collaborate. Members of the project organization felt the emotional necessity to develop good relations with their coworkers. Their drive to collaborate generated engagement in work and social 
INDEPENDENT JOURNAL OF MANAGEMENT \& PRODUCTION (IJM\&P)

http://www.ijmp.jor.br

v. 8, n. 2, April - June 2017

ISSN: 2236-269X

DOI: 10.14807/ijmp.v8i2.556

activities that helped them to know one another better and to learn from each other. This strengthened the nature of their collaboration and encouraged open sharing of information and knowledge (DIETRICH et al., 2010; WHEATLEY, 2003, REEVES, 2004; DARLING; ROSS, 2000).

\subsection{Crafting Reciprocal Relationships}

Crafting reciprocity affirmed the worth of each partners' contribution to the project and promoted an emotionally healthy work environment. This is consistent with the work of Gittell, (2016); Hodson, (2001, 2005); Weymes, (2003); and Wheatley, (2003).

In an emotionally healthy work environment each project partner reinforces trust and interdependence through collaborative problem solving. In the Panama Canal Expansion Program, collaboration became a pragmatic process wherein project partners mitigated the dissonance inherent cross cultural collaboration and over time obviated the need for submarining, or what Towers Perrin (2003) call "rational endurance."

In essence, partners were building social and political capital by building social trust.

\subsection{Build Social Trust}

Trust is essential to the collabyrinth journey and is dependent on situational and affective factors that influence how actors commit to their organizations (e.g., the project organization) and to each other (GITTELL, 2005, 2016). Trust evolved from execution strategies that were sensitive to the tenor of relationships among and between partners.

Seeking consent and crafting reciprocal relations framed the cognitive and affective character of the relationship network within the holding environment. Moving to this point in the collabyrinth was based on the antecedent experience with one another (e.g., from conflicting conditions to seeking consent). Participants were willing to trust enough to collaborate so each partner's unique contribution can be realized and reach synergy.

Nearly two decades ago Darling and Russ (2000) argued that organizations are no longer built on economic force alone, but on trusting, collaborative relationships. This suggests the importance of balancing tasks and relationships, 
INDEPENDENT JOURNAL OF MANAGEMENT \& PRODUCTION (IJM\&P)

http://www.ijmp.jor.br

v. 8, n. 2, April - June 2017

ISSN: 2236-269X

DOI: 10.14807/ijmp.v8i2.556

which is challenging in contentious, culturally complex environments. Collaborative practices overcame perceived inequities and the negative politics (e.g., the forerunners of crisis as in the original tender process) associated with mega projects (e.g., the Seattle Tunnel Project or Boston's "Big Dig"). This made social trust a necessary practice for constructing the reciprocal relations necessary for creating synergy.

Trust influenced the holding environment's social structure, the exchanges therein, and sense of justice as evidenced in shared events especially in regard to decision making. Authority hierarchy and spatial distance positively correlated with organizational politics and spatial distance factors were consistent with Van Marrewijk and Smits (2014).

\subsection{Nurturing Sustainable Relationships}

There is no collaboration without sustainable relationships. Sustainable relationships reinforce the relational coordination connecting project partners to one another through understood rules, behaviors, and purpose. These elements were critical to collaborating on the project's execution strategy. Sustainable relationships evolve from dense networks of reciprocal social and political capital.

They require dependability and accountability. Dependability is being present to others through the good and bad times. Accountability is being responsible for manifesting personal and professional commitment to collaboration and to mitigating submarining/rational endurance. Links between sustainable relationships and project identity were affirmed.

Synergy maintained the goodwill necessary for sustained collaboration within the project organization. Systemic solidarity flowed from dense relationships that were connected through social and political capital. The inference is that social and political capital comes from sustained positive reciprocal relations (i.e. collaboration).

Synergy forged positive social and political connections among and between project partners and over time partners formed friendships of varying strength and intensity. The power of relationality was in the actions leaders chose to take to promote sustained collaboration. This made collaboration a choice. Participants chose to participate or not to participate - which was emphasized by seeking 
consent. Social and work events acknowledged individuals and project partners as being more than their work product alone.

Ultimately, synergy was driven by realizing the criticality of the project's mission to make a positive difference. This drove accountability, job satisfaction and trust. How a collaborative relationship network actually works in cross-cultural projects is determined by the layered elements of its culture and is sustained through interdependence, reciprocity and cultural intelligence (LIVERMORE; ANG, 2015; LIVERMORE, 2011).

Engagement manifested ongoing, responsive learning based on antecedent experience, as noted above. High priority was placed on nurturing the trust and collective intelligence for collaborating in a multicultural social structure within an unstable holding environment. The Panama Canal Expansion Program suggests that social structure influences collective knowing and mission performance and therefor cohesive and ongoing.

In the conflicting conditions stage of the collabyrinth journey the structural embeddedness of corporate culture influenced execution-oriented tasks, whereas relationality in seeking consent and crafting reciprocity influenced innovation-oriented tasks. This would seem to emphasize that the Expansion Program ended up being about relationships and results. Indeed, we suspect that the journey through the collabyrinth is about forming relationships to get to results.

Those with process knowledge to influence how resources were used had to integrate tacit and explicit knowledge with that of other projects partners. Sharing project partners' tacit and explicit knowledge promoted genuine collaboration based on crafting trust and reciprocity.

\section{RECOMMENDATIONS FOR FUTURE RESEARCH}

Future research may prove helpful in understanding how cross-corporate cultural conflict works in mega projects, especially those layered with cultural complexity. For example:

(1) To what extent, if any, do Bolman and Deal's $(2013,2014)$ concept of organizational frames influence collaboration when each corporate culture has a predominant frame that differs from the other partner organizations? 
(2) How do Edgar Schein's conceptualizations of Humble Inquiry (2013) and Humble Consulting (2016) relate to seeking consent and forming reciprocity in the collabyrinth journey?

(3) If collaboration depends on ongoing engagement through sustainable relationships, what are the tools most critical to developing and maintaining sustained engagement and are they generalizable to most project endeavors?

\section{CONCLUSION}

Work is where we spend most of our time and invest in most of our relationships. The Collabyrinth journey mints the social and political capital necessary to achieve results that are shaped by a unifying theme that builds faith and hope in actions that build a better future. In this case, that better future was the increased flow of trade and goodwill among and between the global trading partners.

When faced with the challenge of executing a mega project in a culturally complex holding environment partners must continually re-examine the thematic unity of their project organization's culture. Partners must understand that a part of their individual corporate culture must give way to the "Emergent We" formed by the collabyrinth journey.

Execution strategy must respect each project partner's sources of legitimacy. Ignoring sources of legitimacy undermines the social and political capital structures within the holding environment and can lead to conflict and crisis. Conflict and some level of crisis are inevitable in any project endeavor. It is therefore important to, from the commencement of the project, to recognize the symptoms of crisis and have mechanisms in place for crafting reciprocal relations so partners can construct the relational foundation to resolve issues based on relational values and desired project outcomes. Laying this foundation supports project partners' efforts to reach synergy, the ultimate goal of intercultural collaboration, and to achieve effective and efficient results. Therein lies the answer to our research question. Figure 2 maps the integration of crisis management and the Collabyrinth journey.

The complexity of mega projects politicizes execution strategy due to competing priorities among and between project partners. This requires adaptive changes that are entwined with stories, metaphors, and dialogues about the past, present, and future. Project organization memory is not obliterated by change but 
INDEPENDENT JOURNAL OF MANAGEMENT \& PRODUCTION (IJM\&P)

http://www.ijmp.jor.br

v. 8, n. 2, April - June 2017

ISSN: 2236-269X

DOI: 10.14807/ijmp.v8i2.556

kept alive through adaptation that honors the network of relationships that brought the project to its present point in time. Honoring that network, and those within it, drives the synergy that makes working together for something beyond ourselves worthwhile.

\section{REFERENCES}

BOIN, A.; T HART, P.; STERN, E.; SUNDELIUS, B. (2005) The politics of crisis management: Public leadership under pressure, New York: Cambridge University Press.

BOLMAN, L.; DEAL, T. (2013) Reframing Organizations: Artistry, Choice \& Leadership, John Wiley \& Sons, San Francisco.

BOLMAN, L.; DEAL, T. (2014) How Great Leaders Think: The Art of Reframing, Jossey-Bass, San Francisco.

BOUD, D.; CRESSEY, P.; DOCHERTY, P. (2006) Productive Reflection at Work: Learning for Changing Organizations, New York: Routledge.

BRESNEN, M.; MARSHALL, N. (2011) Projects and Partnerships: institutional processes and emergent practices, in: MORRIS, P. W. G.; PINTO, J. K.;

SÖDERLUND, J. (Ed.), The Oxford Handbook of Project Management, Oxford: Oxford University Press, p. 154-174.

BROWNLOW, R. (2007) Finding Way: Post-Teachers' Strike Relationship Recovery and School District Renewal. Doctoral Dissertation, Seattle: Seattle University.

BROWNLOW, R. (2011) Reflective-Heuristic Practice, Crisis Management an Charleston, SC: d Simulation: An Integrated Methodology, in: KIRSTEIN, K.; HINRICHS,J.; OLSWAG, S. (Ed.) Authentic Instruction and Online Delivery: Proven Practices in Higher Education, Charleston: CreateSpace Publishing, p. 147 - 168.

CLAUSEN, L. (2007) Corporate Communication Challenges: A 'Negotiated' Culture Perspective, International Journal of Cross Cultural Management, v. 7, p. 317332.

DARLING, J.; RUSS, D. (2000) Relationship capital. Executive Excellence, v. 17, n. 5, p. 14.

DIETRICH, P.; ESKEROD, P.; DARLCHER, D.; SANDHAWALIA, B. (2010) The Dynamics of Collaboration in Multipartner Projects. Project Management Journal, v. 41 , n. 4 , p. $59-78$.

ENGWALL, M. (2003) No project is an island: linking projects to history and context. Research Policy, v. 32, p. 789-808.

FLYVBJERG, B.; HOLM, M. S.; BUHL, S. (2002) Underestimating Costs in Public Projects. Error or Lie? Journal of the American Planning Association, v. 68, n. 3, p. 279-295.

GITTELL, J. (2005) The Southwest Airlines way: Using the power of relationships to achieve high performance. New York: McGraw-Hill. 
GITTELL, J. (2016) Transforming Relationships for High Performance: The Power of Relational Coordination. Stanford: Stanford University Press.

GRABHER, G. (2002) Cool Projects, Boring Institutions: Temporary Collaboration in Social Context. Regional Studies, v.36, n.3, p. 205-214.

HARTMANN, A.; BRESNEN, M. (2011) The emergence of partnering in construction practice: an activity theory perspective. The Engineering Project Organizational Journal, v. 1, p. 41-52.

HEIFETZ, R. A.; LINSKY, M. (2002) Leadership on the line: Staying alive through the dangers of leading, Boston: Harvard Business School Press.

HODSON, R. (2001) Dignity at Work, New York: Cambridge University Press.

HODSON, R. (2005) Management behavior as social capital: A systematic analysis of organizational ethnographies, British Journal of Industrial Relations, v. 43, n. 1, p. 41-66.

HOFFMAN, B. G. (2012) American Icon: Alan Mulally and The Fight to Save Ford Motor Company, New York: Crown Business.

JOSSERAND, E.; CLEGG, S.; KORNBERGER, M.; PITSIS, T. (2004) Friends or Foes? Practicing Collaboration - An Introduction, M@n@gement, v. 7, n. 3, p. 3745.

MARTIN, A.; HAGAN, D.; RUTYNA, B. (2004) Collaborative Change Practice: Embedding Actionable Knowledge in Real Work, Academy of Management Proceedings, p. C1-C6.

MILES, M. B.; HUBERMAN, A. M. (1994) An expanded source book: Qualitative data analysis, 2 ed, Thousand Oaks: Sage Publications.

MORAN, P. (2005) Structural vs. relational embeddedness: Social capital and managerial performance. Strategic Management Journal, v. 26, n. 12, p. 11291151.

MORRIS, D. (1993) The Meanings of Pain, in: The Culture of Pain, Los Angeles: University of California Press, p. 31-56.

MEZIROW, J. (1991) Making meaning through reflection, in: Transformative dimensions of adult learning, San Francisco: Jossey Bass, p. 91 - 117.

PUTMAN, R. D. (2000) Bowling alone: The collapse and revival of American community, New York: Simon \& Shuster.

PUTNAM, R. D. (2004) Democracies in Flux: The Evolution of Social Capital in Contemporary Society, New York: Oxford University Press.

REEVES, R. (2004) Friendship is the invisible thread running through society. New Statesman, v. 133, n. 4684, p. 29-32.

SCHEIN, E. (2013) Humble Inquiry: The Art of Asking Instead of Telling, San Francisco: Barrett-Koehler Publishers.

SCHEIN, E. H. (2016) Humble Consulting: How to Provide Real Help Faster, Oakland: Barrett-Koehler.

SCOTT, W. R.; LEVITT, R. E.; ORR, R. J. (2011) Global Projects. Institutional and Political Challenges. Cambridge: Cambridge University Press. 
SMITS, K. (2013) Cross Culture Work: Practices of Collaboration in the Panama Canal Expansion Program, Delft: Next Generation Infrastructures Foundation.

SMITS, K.; VAN MARREWIJK, A. (2012). Chaperoning: Practices of Collaboration in the Panama Canal Expansion Program. International Journal of Managing Projects in Business, v. 5, n. 3, p. 440-456.

SMITS, K.; VAN MARREWIJK, A.; VEENSWIJK, M. (2015). The Collabyrinth of Cross-cultural Collaboration in the Panama Canal Megaproject, in: VAN MARREWIJK, A. (Ed.), Inside Megaprojects: Understanding the Cultural Practices in Project Management, Copenhagen: CBS Press, p. 103-136.

SCHWARTZ-SHEA, P.; YANOW, D. (2012) Interpretive Research Design: Concepts and Processes, New York: Routledge.

TOWERS PERRIN HR SERVICES (2003) Working today: Understanding what drives employee engagement: The 2003 Towers Perrin Talent Report. Available: http://www.keepem.com/doc_files/towers_perrin_talent_2003(thefinal).pdf Access: October 14 $4^{\text {th }}, 2016$

VAN MARREWIJK, A.; CLEGG, S.; PITSIS, T.; VEENSWIJK, M. (2008) Managing public private megaprojects: Paradoxes, complexity, and project design. International Journal of Project Management, v. 26, p. 591-600.

VEENSWIJK, M.; BERENDSE, M. (2008) Constructing new working pratices through project narratives. International Journal Project Organisation and Management, v. 1, n. 1, p. 65-85.

WELCH, C.; PIEKKARI, R.; PLAKOYIANNAKI, E.; PAAVILAINEN-MÄNTYMÄKI, E. (2011) Theorising from case studies: Towards a plurist future for international business research. Journal of International Business Studies, v. 42, p. 740-762.

WEYMES, E. (2003) Relationships not leadership sustain successful organizations, Journal of Change Management, v. 3, n. 4, p. 319-332.

WHEATLEY, M. J. (2003) Turing to one another, San Francisco: Berrett-Koehler Publishers, Inc.

YANOW, D.; TSOUKAS, H. (2009) What is reflection-in-action? A phenomenological account, Journal of Management Studies, v. 46, n. 8, p.1339-1364

YBEMA, S.; YANOW, D.; WELS, H.; KAMSTEEG, F. (2009) Organizational Ethnography: Studying the Complexities of Everyday Life, London: Sage 